\title{
Military Operations Research: Origins, Recent Past, and Present
}

Askeri Yo̊neylem Araştırması: Kökenler, Yakıı Geçmiş ve Bugůn

Uğur Ziya YILDIRIMำ

Araştırma Makalesi

1 Dr.

ID ORCID: 0000-0001-9383-5039

Sorumlu yazar/Corresponding author:

Uğur Ziya YILDIRIM

E-posta/E-mail:

ziyayildirim@gmail.com

Geliş tarihi/Received:

15 Nisan 2021

\section{Revizyon talebi/Revision}

Requested:

26 Nisan 2021

Son revizyon /Last revision:

29 Nisan 2021

\section{Kabul tarihi/Accepted:}

30 Nisan 2021

\section{Atıf/Citation:}

Yıldırım, Uğur Ziya. "Military Operations Research: Origins, Recent Past, and Present". Türk Savaș Calismalar Dergisi 2, no. 1 (2021): 01-16.

\begin{abstract}
Operations Research (OR) (also called Operational Research and Operations Analysis) has its origins in tackling military problems and requirements using scientific methods and common sense. This paper aims to provide an overview of its origins, a summary on recent past, and current practices. While many ingenious persons have come up with creative ways to ensure the military means and tools that were more effective and efficient over the centuries, not all of these individual efforts can qualify as an organized scientific discipline. Thus, it is important to note that the author refrains from the premise of "the older the better" and focus of the paper is on "practical" emergence of OR as an "applied science" in the years just preceding and during World War II (WW2). Military applications of OR, where it stemmed from, are provided throughout the paper. After WW2, unemployed OR analysts started using their skills on making things better, more effective, and more efficient in the civilian industry and this tradition continues today with great success. It would be over ambitious to attempt to cover all of OR's applications and contributions in a single paper. Therefore, the attempt here is to provide a glimpse of Military OR's origins, recent past, current application areas.
\end{abstract}

Key Words: military operations research, operations analysis, operational research, World War II, applied science

Özet

Harekat Araştırması (HA) (Türkiye'deki yaygın ismiyle Yöneylem Araştırması, Harekat Analizi)'nın çıkış yeri askeri problem ve ihtiyaçlara bilimsel yöntemler ve genel mantık çerçevesinde çözüm bulma çabası ile başlamıştır. Bu makale HA'nın başlangıcı, yakın geçmişi, mevcut uygulamaları ile ilgili özet bilgiler sunmayı amaçlamaktadır. Yüzyıllar boyunca birçok zeki insan askeri yöntem ve araçların daha etkin ve verimli olmasının yaratıcı yollarını bulmaya çabaladıysa da, bu bireysel gayretler bilimsel bir disiplin olarak adlandırılamaz. Yazarın "daha eski daha iyidir” anlayışından uzak durduğunu not ederek, makalenin 2nci Dünya Savaşı esnasında ve hemen öncesinde HA'nın "uygulamalı bir bilim" olarak ortaya çıkışı ve buna ait pratikteki uygulamalara odaklanacağını belirtmek gerekir. 2nci Dünya Savaşı sonrasında işsiz kalan HA analistleri yeteneklerini sivil hayattaki endüstrinin sorunlarına daha iyi, daha etkin ve daha verimli çözümler üretmede kullanmaya başladılar ve bu günümüzde de büyük bir başarı ile devam etmektedir. HA'nın tüm uygulamalarını ve katkılarını tek bir makalede özetlemeye çalışmak çok fazla iddialı bir gayret olacaktır. Bu yüzden, buradaki amaç Askeri Harekat Araştırmasının kaynağı, yakın geçmişi ve mevcut uygulama alanları hakkında özet bilgi sunmaktır.

Anahtar Kelimeler: askeri harekat araştırması, harekat analizi, yöneylem araştırması, 2nci Dünya Savaşı, uygulamalı bilim 


\section{INTRODUCTION}

This paper aims to provide an overview of the origins of Operations Research (OR, also called Operational Research and Operations Analysis), a summary on its recent past, and current practices. As this review paper argues OR has its origins in tackling military problems and requirements using scientific methods and common sense in the years just preceding and during World War II (WW2). Earlier studies of scientists such as Archimedes (287-213 B.C.), Leonardo Da Vinci (1452-1519), Galileo Galilei (1564-1642), and a few others are often cited as initial examples of OR by the so-called forefathers of OR. While many ingenious persons have come up with creative ways to ensure the military means and tools were more effective and efficient over the centuries, not all of these individual efforts can qualify as an organized scientific discipline. Thus, it is important to note that the author refrains from the premise of "the older the better" and focus of the paper is on "practical" emergence of OR as an "applied science" in the years just preceding and during World War II (WW2). Military applications of OR, where it stemmed from, are provided throughout the paper. After WW2, unemployed OR analysts started using their skills on making things better, more effective, and more efficient in the civilian industry and this tradition continues today with great success. It would be over ambitious to attempt to cover all of OR's applications and contributions in a single paper. Civilian applications of OR are not covered here. The author restricts, intentionally, the review to only the military applications of OR during its origins. In order to show the evolution of this applied discipline to its current state, recent and current examples are also provided. Therefore, the attempt here is to provide a glimpse of Military OR's origins, recent past, and current application areas.

\section{RADAR AND OPERATIONS RESEARCH IN THE YEARS PRECEEDING WW II}

Operations Research (Operations Analysis or Operational Research, the original name coined in Britain during WW2) came out of the need for the defence of Britain against imminent air attack from German Air Force (Luftwaffe). It was closely associated with the radar for the same need and also because those scientists involved in the development of radar and its applications for defense of Britain ended up being its pioneers. After Hitler came to power in 1933 and decided to build an air force that would match or surpass those of France and Britain combined, it was simply a race against time on whether Britain would build enough defences against this emerging threat. Since the British Isles was about 70 miles from European shore and only at a mere 17minute flying distance for the German bombers that would later be built, there existed no means of early warning and tracking of attacking aircraft that would allow British bombers enough time to take off and reach enough altitude to fight off enemy aircraft before they could penetrate inland. ${ }^{1}$

Such an early warning system would be called a Command, Control, and Information System today. By 1935, Royal Air Force's (RAF) committee for the Scientific Survey of the Air Defences wanted to know if a so-called "death ray" could be used against German fighters to incapacitate/kill the pilot or disable the aircraft. ${ }^{2}$ Such a technology was not available and even if it were, the incoming aircraft's location, altitude, and direction would have to be determined in order to target it with the beam. This realization reinforced the need for further development of the radar

\footnotetext{
${ }^{1}$ Larnder, Harold. “OR Forum—The Origin of Operational Research.” Operations Research 32(2):465-476. (1984)
}

2 Ibid 469. 
and its employment on land and on aircraft for early warning purposes in the years leading to the start of the War. Thus, the full-scale research on radar technology started. The research teams composed of scientists from multiple disciplines.

By 1936, Bawdsey Research Station was established on the east coast of Britain near Felixstowe, Suffolk. This place became the centre of all radar research during pre-war years and the experimental radar equipment became more reliable and able to detect aircraft over 100 miles. By 1937, this experimental radar station became operational and started feeding information into the air defence warning and control system. Four more stations were operational by 1938, yet even though they were technically sound, there was a need to correlate and deconflict the information received through additional radar stations. Thus, there existed a need to research the operational aspects of this new device rather than its technical aspects. This is how the term "Operational Research" was coined in Britain to describe this new applied science to meet operational requirements of the military. Several teams of scientists were formed to look into different aspects of operational needs such as deconflicting or correlating information received from radars and the observers on the ground, research into the techniques to control formations of fighters against German bombers during daylight, and later on control of single fighters against single bombers at night. ${ }^{3}$

Three major field experiments were held over the years to test the operational readiness of the radar and the air defence warning and control system. The largest of those was held in summer of 1939 with participation of " 33,000 men, 1,300 aircraft, 110 anti-aircraft guns, 700 search lights, and 100 barrage balloons". ${ }^{4}$ As a result of these experiments between 1936 and 1938, radar was integrated into air and land early warning systems and into direction and control systems of fighter planes. Impressed by the improvements in the operation of the early warning and control system brought about by the operational research teams, the commanding officer of the RAF Fighter Command requested that the teams be attached to his headquarters in Stanmore and named "Stanmore Research Section". This took place on 3 September 1939 before the Battle of Britain started in July 1940. The Section was redesigned and named the "Operational Research Section" and the term was officially recognized and accepted. Similar sections would be set up at different RAF commands and also at Coastal Command, Royal Navy, Army Commands, and overseas in the following years. ${ }^{5}$

Most of the support provided by the operational analysts up to this point has been tactical in nature and also recommendations about technical deficiencies or reliability problems in equipment. The data was observed and collected, analysed and recommendations on employment of aircraft considering differences in their performance, Anti-Aircraft (AA) guns, and radars were made. OR support affecting bigger policy decisions would come later during the War.

\footnotetext{
${ }^{3}$ Ibid 471.

${ }^{4}$ Ibid 471

${ }^{5}$ Ibid 471.
} 


\section{OPERATIONS RESEARCH DURING WWII AND FURTHER APPLICATIONS}

Originally, Operations Research in Britain was practiced improving defensive operations. The Battle of Britain involved coordinated use of radar stations inland and near the coastline, the Observer Corps inland, AA guns, fighter aircraft patrolling over high-value target areas, and fighter aircraft scrambled to meet and greet enemy aircraft as they crossed the coastline. Fighter pilots were on their own when they met the intruders and received no help from ground stations. This tactic could not change a whole a lot since the Battle of Britain lasted just over a month and offered almost no chance for change. These tactics were adequate for daylight engagements. Yet, several successful night attacks of the Luftwaffe proved that the chain of radar stations would not suffice when the enemy concentrated on night attacks. Thus, the Fighter Command recommended the development of Ground Control Intercept (GCI) equipment and techniques to be implemented with a new Airborne Intercept (AI) radar with a range of 3-4 miles. These were not available during the night battles called Blitz in September and October 1940. However, they became available for use spring of 1941. Luckily, Germans had to cancel the Blitz due to increasing number of bomber losses, i.e., 7 percent in May $1941 .^{6}$

As the War progressed, contributions of OR Section of the Fighter Command turned towards providing support for offensive capabilities of the British War machine. The end of the Blitz in 1941 and the lessons learnt during it basically meant three things in terms of the contribution of OR for the war effort. The first was, through the modification of existing radar equipment and addition of altitude finding equipment, the creation of the fighter direction station. This was basically a radar-based system to provide direction and control for offensive aircraft in contrast to the defensive system employed during the Battle of Britain. The second was the development of jammer equipment against German warning systems and the third was basically an IFF (Identify Friend or Foe) system developed to ensure that increased US Air Force participation in the attacks were conducted safely.?

Initially, analyses to support defensive operations has concentrated on equipment development, reliability, and maintenance issues with the help of physicists, communications engineers, and signal personnel. With the offensive phase of the War against German targets in France, the focus was now on the analysis of huge data that included gun-camera footage, from the air engagements and later on from ground strafing, namely the practice of attacking ground targets from low-flying aircraft using automatic weapons on board, and rocket attacks against the enemy from the fighters. The firing of the rocket projectiles was analysed based on their curved trajectories, sensitivity to range, and the dive angle of the aircraft during the attack. The dive angles and range recommendations of the OR analysts paid dividends during attacks against enemy communications lines, radar stations, and bridges in northern France in preparation for the invasion and liberation of France. A new gunsight for the fighters was introduced in 1944 as a result of the analysis of air combat engagements. This entailed adjustments to include the effect of

\footnotetext{
${ }^{6}$ McCloskey, Joseph F. “OR Forum-British Operational Research in World War II.” Operations Research 35(3):453470. (1987)

${ }^{7}$ Ibid 455.
} 
the angle of attack, and the closing range, the effect of experience, and special training in the use of the new gunsight. ${ }^{8}$

OR support for a policy decision, as opposed to tactical ones, would come in May 1940 regarding the 10 fighter squadrons that had deployed to the European Continent to counter the German offensive against France and the Benelux countries. British losses were mounting at a rate of around three squadrons every two days, which was not sustainable and such losses would eventually endanger the defence of British homeland. On May 14, the French Premier asked Churchill for an additional 10 squadrons and Churchill was inclined to accept this request. However, Air Chief Marshal Hugh Dowding, commander of RAF Fighter Command, was thinking this to be a fatal mistake and thus asked his OR analysts, after explaining his rationale, to prepare a document to support his case in two hours before he departed for the War Cabinet meeting on 15 May. The analysts rapidly produced daily attrition figures, replacement rates, and what would have happened if the losses were to double with constant replacement rates. In addition to displaying the analysis in tabular format, they also produced graphics relating losses, time, and force levels to show the rate at which the Fighter Command's strength would reach unacceptable levels. During the meeting, feeling that his comments were not reaching the audience, Dowding got up, walked around the table to the Prime Minister in order to persuade through the eyes instead of ears, laid the graphs in front of Churchill and said, "If the present rate of wastage continues for another fortnight, we shall not have another Hurricane (fighter plane) left in France or in this country". As a result, additional 10 squadrons were not sent to France and all, but three squadrons deployed back to Britain. The real value of this OR study was in the way the analysts presented the facts to prevent a fatal error in decision making. ${ }^{9}$ After all, a picture tells a thousand words!

As with all the other branches of military, the Coastal Command also had its teams of analysts. The antisubmarine operations, convoy protection, and attacking on enemy shipping were major tasks for the British Coastal Command. These were primarily offensive in nature and they offered ample opportunities for the practice of operations research. As opposed to the short duration of the Battle of Britain, the war at sea against German surface ships and U-boats and the protection of friendly convoys and shipping continued till the end of the War. The British had the upper hand due to intelligence gathered via breaking the code of encrypted communications of the German Armed Forces through Enigma. Yet, there were still problems requiring solutions regarding navigation, search and detection, identification of enemy sub-surface and surface assets, bombing accuracy, and battle damage assessment. ${ }^{10}$

OR analysts wanted to improve the effectiveness of attacks against U-boats using depth charges dropped from ships and aircraft. The ships had the advantage of sonar to detect submerged U-boats, but they had to be away from the explosion site. Aircraft of the Coastal Command, on the other hand, had no way of detecting submerged submarines, but they did not need protection from the detonation. The charges dropped from ships were set to detonate at 100 feet under water in order to allow the surface vessel enough time to get to a safe distance from the explosion site. Yet, by the time the depth charge reached 100 feet, the submarine would submerge

\footnotetext{
${ }^{8}$ Ibid 455.

${ }^{9}$ Larnder, Harold 473 (1984)

${ }^{10}$ McCloskey, Joseph F. 455 (1987).
} 
and manoeuvre away from where the depth charges were dropped. Furthermore, the effective radius of the charges were only 20 feet and not very effective. The solution was to set the depth charge to go off at 35 feet and to give up any attack on a submarine that had been submerged for 15 seconds or more. Later with technical advances on the fuse, this depth was brought to 25 feet. In addition to the depth of the charge, the best means of deploying them from aircraft were also explored via camera footage data on aiming errors. Best methods of employing depth charges regarding size, spacing between them when dropping from the aircraft, and aiming methods were provided by the OR analysts. ${ }^{11}$ The results were an increase of 400 percent in the destruction of $\mathrm{U}$ boats by the Royal Navy and an increase of 700 percent by the RAF. Germans were reporting that the increased attrition rates of their submarines were due to the employment of more powerful bombs by the British, whereas they were the same weapons employed more efficiently and effectively by the recommendations of OR analysts. ${ }^{12}$

In the second half of 1941, Air to Surface Vessel (ASV) radar for the Coastal Air Command became available. This caused the German submarines to try to transit into the Atlantic at night. The radar on the aircraft could bring it close to the submarine, but not close enough to precisely locate it. This precision issue was solved by installing powerful search lights on the aircraft. It was so effective that the Germans went back to day-time transit, yet they had to submerge more frequently, thus slowing their transit time to the Ocean via Bay of Biscay. Yet, they were still able to reach and attack sea lanes. In response, Germans developed a device that could tell the submarine commander if his ship was under radar surveillance. As a countermeasure, the British modified the ASV radar to employ cavity magnetron, thus allowing it to become less detectable by the Germans with an increased effective range. This cutting-edge technology at the time heralded the start of the end of U-boat threat. ${ }^{13}$

Royal Navy wanted to determine the appropriate size of merchant convoys, escort ships and aircraft so that the losses from U-boat attacks would be minimized. The general agreement was the more escort vessels and aircraft one had, the fewer would be the losses. Yet, they were not available and the only variable to experiment with was the size of the convoys. Thus, the size of the convoys was increased as much as possible. ${ }^{14}$

By the same analogy, the OR analysts recommended larger bomber plane formations for night raids due to the lack of fighter escorts. This led to the first 1000-plane attack on Cologne in May 1942. One safety concern during such large formations of aircraft was the danger of collision of friendly aircraft. The OR analysts' estimate was one collision and it turned out to be a true estimate. $^{15}$

Selecting a proper measure of effectiveness with sound analysis is important for the OR analysts. One example of this during WW2 had to do with the fact that RAF's utilization of planes had been based on the availability of aircraft rather than on the missions required to be flown. 70-

\footnotetext{
${ }^{11}$ McCloskey, Joseph F. 456 (1987).

12 Gaither, Norman. "Historical Development of Operations Research (1940-1960)". Academy of Management. Published Online:13 Dec 2017.

${ }^{13}$ McCloskey, Joseph F. 457 (1987).

${ }^{14}$ Gaither, Norman. 71 (2017).

${ }^{15}$ McCloskey, Joseph F. 458 (1987).
} 
$75 \%$ of serviceable aircraft was taken as the criterion. However, the OR studies revealed that schedule missions could be flown even when serviceability levels dropped below $50 \%$. This led to the schedules being based on missions to be flown, eventually reducing service crew requirements for maintenance and allowing the achievement of more flying hours. ${ }^{16}$

The ground-launched cruise missiles of today were the V1 unmanned pulse-jet engine flying bombs. They presented a challenge for the Heavy AA (HAA) and Light AA (LAA) guns of the day since V1 flew at such an altitude that was too low for the HAA and too high for the LAA. Even if it was shot down, it would cause serious damage if it still had the unexploded warhead.

Furthermore, the radars in their current positions were not able to detect them once launched from sites in France because of the rolling terrain features between the coastline and the cities in southern England including London. After careful analysis and some unsatisfactory deployments to locations without any concrete and positive results in terms of radar coverage and successful shot-downs, radars and guns were all moved in a massive deployment in a short time to a narrow-belt at the English Channel where they had an unobstructed line of sight over the sea and could even see them being launched from France on clear nights. This also prevented collateral damage since those V1s shot over the water would not cause any damage. ${ }^{17}$

OR analysts of the US were in close cooperation with their British Allies contributing in solving of many of the issues explained above. One example of the US OR effort towards the end of the War in the Pacific was the analysis and recommendations provided against the Kamikaze attacks. Ship commanders were not able to decide whether to manoeuvre violently or keep straight to better aim with the AA guns onboard while under Kamikaze attack. Through careful analysis, Navy's OR group recommended large ships should manoeuvre violently and small ships should change course slowly. It was observed that those ships under attack that followed those recommendations were hit 29 percent of the time, while those that did not adhere to the recommendations were hit 47 percent of the time. ${ }^{18}$

There are ample examples of OR that helped make a difference during the War. It is impossible to list them all here. The examples provided thus far should enable the reader to understand that OR is an applied science that originated from the need to find multi-disciplinary solutions to military operational problems and hint about the different types of problems the analysts had to deal with during those days. Many of these problems still persist today in similar or substantially different forms. Nowadays, the OR analyst is better prepared and armed to deal with them.

\section{RECENT APPLICATIONS OF MILITARY OR}

Military OR has come a long way since its origins in the years preceding and during WW2. The techniques and tools developed after WW2 such as linear programming, game theory, other optimization techniques such as non-linear and dynamic programming, stochastic analysis methods, invention of computers, ever-increasing computing power available to analysts, designs

\footnotetext{
${ }^{16}$ Ibid 457.

${ }^{17}$ Lindsey, George. "Some Personal Recollections of Army Operations Research on Radar in World War II". Canadian Military History. Vol. 4: Issue 2, Article 8. (1995).

18 Gaither, Norman. 74 (2017).
} 
of experiments, modelling and simulation, data science, statistical methods, and many other tools that armed today's analysts meant more sound and precise analysis with increased insights to old and new problems.

The type of analysis conducted by OR analysts have to answer the burning issues and problems of the day and near future. If one looks at the recent applications of military OR, e.g., those between 2009 and 2014, it is clear that major concerns of decision makers and naturally OR analysts, concentrated on counterinsurgency operations that came about and continued after invasions in Afghanistan and Iraq. Such large-scale invasions and military operations also brought about the need for nation-building efforts. To predict, prevent, and prepare for future instabilities, thus, became a cause for concern for policy makers and the analysts who supported them. These problems still persist and keep analysts busy. A few examples of such recent applications of military OR are presented here to allow the reader to appreciate the different types of evolving support provided by the OR analysts.

Abdollahian, Mark, Brice L. Nicholson, Matthew Nickens, et al. "A Formal Model of Stabilization and Reconstruction Operations" Military Operations Research, vol. 14, no. 3, pp. 5-30 (2009)

Policy makers have been trying to answer questions such as which factors to modify to stabilize a conquered nation with an active insurgency, how to accurately forecast capacity to stabilize specific nations after combat, which factors are the most essential for stabilization and reconstruction $(\mathrm{S} \& \mathrm{R})$ operations, how should $\mathrm{S} \& \mathrm{R}$ objectives shape planning and operations during combat, the length of the S\&R operation, the amount of foreign aid required, and the level of multilateralism. The authors present a differential equations-based model of stabilization and reconstruction after major combat operations. They test their model using regression techniques with empirical data from six S\&R operations that took place after 1945. These are the S\&R operations in Germany, Japan, Somalia, Haiti, Balkans, Afghanistan, and Iraq. The types of military missions for those nations listed are respectively regime change-reconstruction, partial regime change-reconstruction, humanitarian aid-regime change, regime change-S\&R, stop ethnic cleansing-S\&R, regime change-S\&R, and regime change-S\&R. The variables considered are previous state of society/economy, the level of damage caused by military action, continuing hostile activities, post conflict duration, troops per capita, foreign aid \& investment, multilateral involvement, and degree of success. In developing their model, they rely on three common basic assumption in the $S \& R$ literature. These are: given sufficient levels of the aforementioned variables, nations can be stabilized, outcomes can be shaped by the occupying nation's policy, and preexisting conditions after major combat operations (initial starting conditions) are determinants of the resources required for $S \& R$ operations. Based on existing literature and empirical evidence, the list of variables for their model are classified as endogenous and exogenous variables. The endogenous variables are Damage to Infrastructure, Casualties, Institutional Strength, and Domestic Support for S\&R Operation in Occupying Nation, Guerrillas per Thousand Population. The exogenous variables are Foreign Aid Investment, Troops per Thousand Population, Length of Operation, and Multilateralism. Germany and Japan are listed as great examples of S\&R effort, whereas Somalia was one the worst failures. Their model also accurately predicted this failure. Furthermore, their model postulates that Somalia operation could have been a success had the 
initial force levels and the foreign aid level been sustained at their initial levels for an additional 36 months. On the other hand, the operation in Bosnia and Herzegovina is listed as one of the more successful S\&R operations in the twentieth century, yet their model failed to predict this historical outcome with a high degree of accuracy. Regarding Iraq, due to lack of data on specific provinces, their model could not make predictions on the outcome of a partition plan of the country on S\&R efforts. Their model projected in 2009 that 48 additional months, expanded multilateralism, a force size of 15 to 25 troops per 1000 population, and expanded foreign aid of around 600 to 800 dollars per capita per annum could enable stabilization in the country. Yet, even though the US had additional funds, it was in no position to provide the additional 230,000 troops required for the S\&R effort. The lesson provided from the S\&R effort in Iraq is that early avoidance of cost (in funds and troop allocation) would ultimately amplify the commitment of resources required for a successful S\&R operation. The authors conclude by providing recommendations to make their model more accurate with more detailed geospatial and temporal data to be able to produce quarterly or monthly estimates and with the addition of more operationally relevant S\&R factors. ${ }^{19}$

\section{Shearer, Robert and Brett Marvin. "Recognizing Patterns of Nation-State Instability that Lead to Conflict". Military Operations Research, vol. 15, no. 3, pp. 17-30 (2010).}

The authors describe a pattern classification methodology developed and adapted for use by the Center for Army Analysis (CAA) in the US as part of the Forecast and Analysis of Complex Threats (FACT) study in 2007. This study postulates that nation-states that experience instabilityrelated conflict are similar with respect to several factors and patterns. Their study replaced several earlier so-called black-box studies and was easier to explain to the less-technically inclined decision makers through a simple geometric interpretation of the pattern classification algorithm. Through validation efforts, they ensured that this methodology could identify those nation-states likely to be involved in instability-induced conflict in the future years. Such a forecast would allow decision and policy makers the leverage to try to prevent and prepare for such contingencies through planning, resource allocation decisions, procurement programs, prepositioning of military assets, language training, and defence planning scenario development to cite a few among many others. They develop Conflict Forecasts and Paths to Conflict predictions for 157 nation-states using data out to 2010, with forecast for following years, using available conflict data from a private organization called Heidelberg Institute of International Conflict Research (HIIK) co-located with the Department of Political Science at the University of Heidelberg. The authors use 13 different feature data of nations from many unclassified sources which are listed in the paper. These are Adult Male Literacy, Caloric Intake, Civil Liberties, Conflict History (from HIIK), Democracy, Ethnic Diversity, GDP per Capita, Infant Mortality, Life Expectancy, Male Unemployment, Political Rights, Religious Diversity, and Trade Openness. They use standard pattern classification algorithms, namely k-Nearest Neighbour and Nearest Centroid, to identify and pictorially depict those conflict-prone nations that would align together based on the 13 features data listed above. The validation and training of the algorithm for classification and forecast accuracy is achieved via a training data set for conflicts between 1993-1997 and a test data set for conflicts with between 1998-2003. One specific forecast they note in the paper regarding conflict forecasts and paths to conflict analysis of 157 nations is about Armenia. They pointed out in 2010 that even though the

\footnotetext{
${ }^{19}$ Abdollahian, Mark, Brice L. Nicholson, Matthew Nickens, et al. "A Formal Model of Stabilization and
} Reconstruction Operations” Military Operations Research, Vol. 14, No. 3, pp. 5-30 (2009) 
HIIK database had not reported conflict in Armenia since 1994, their model's Conflict Forecast for that nation-state was reported as high-conflict potential by $2020 .{ }^{20}$ This turned out to be true via the conflict that took place between Armenia and Azerbaijan in Nagorno-Karabakh and surrounding Armenian-occupied territories between 27 September and 10 November 2020. The technical details of forecast using Principal Components Analysis and Weighted Moving Averages are provided in the paper.

\section{Shearer, Robert. "Operations Analysis in Iraq: Sifting Through the Fog of War". Military Operations Research, Vol. 16, No. 2, pp. 63-71 (2011).}

The author describes his experience as an OR analyst through six cases of analysis support in Iraq in 2008. Some of these cases will be mentioned here. He concludes that a good OR analyst needs a solid background in tools and methods of operations research and also the ability to explain the results of analysis to the war fighters and the decision makers. During his tour in Iraq, he works with two different Corps and thus two different staffs and commanders. During the initial weeks, he notices that the OR section has been preparing literally books of bar charts, each containing at least 50 charts, showing a wide range of trends from casualties, direct and indirect fire attacks, IED (Improvised Explosive Device) attacks, caches found etc. These are updated constantly, and they end up spending most of their effort on this in the OR Section rather than producing actionable analysis for the Command Group. Furthermore, no one in the Command Group or staff seemed to pay any attention to their products. Instead of Excel and its standard charts, they decide to use ArcGIS, a geospatial software package, and display, for example, how the attack density changes over a period of two consecutive months displayed on a military map that the decision makers and staff are familiar with. They also color-coded the density of attacks from low to high on the map. They used a feature in ArcGIS that allowed them to subtract the density of one month form the other to display how fast the attacks changed over time and called it the Attack Velocity. Their analysis was in synch with what the division commanders briefed during updates to the Corps Commander. This was well appreciated for about two months when the Assistant Deputy Corps Commander for Operations said he did not understand and never wanted to see that slide again. The Attack Velocity slide never appeared again, and the analysts realized that explanations of the plots were not understood by the staff. On another occasion and upon a request from a general officer, the OR Section was tasked to see if the insurgents were targeting his trips to various Forward Operating Bases (FOB). After careful analysis of data on attacks and coincidence with the general's trips, they did a hypothesis testing using binomial distribution which revealed that there was no relationship and instead of presenting probability mass functions they simply stated that such a probability would equal rolling three sixes in a row with a die. This seemed to convince the general, yet they advised to remove or hide any indications that the passenger on the helicopter was a general officer. Some of his observations and lessons learned are also mentioned throughout the paper such as: "Proximity to the decision maker is essential; it is hard to have an impact on the

\footnotetext{
${ }^{20}$ Shearer, Robert and Brett Marvin. "Recognizing Patterns of Nation-State Instability that Lead to Conflict". Military Operations Research, Vol. 15, No. 3, pp. 17-30 (2010).
} 
plan if you don't have a seat at the table" or "30 minutes of unfettered access to a senior decision maker is invaluable, even at two in the morning". ${ }^{21}$

\section{Kucik, Paul and Elisabeth Paté-Comell. "Counterinsurgency: A Utility-Based Analysis of Different Strategies". Military Operations Research, vol. 17, no. 4, pp. 5 -23 (2012).}

There are currently ongoing insurgencies in many countries in the World. This paper provides a model of the dynamics of interaction between a government and an insurgent group, at the micro level of a village, in order to assess strategies to control or defeat an insurgency. The model assumes both sides are rational decision makers and provides probabilistic sub-models of actions of government policy makers and insurgent leaders. Policy makers or those in government may have only their political survival when faced with an insurgency, and consequently may focus on short-sighted response to prevent destructive violence without considering long-term effects of their policies and addressing the root causes of the insurgency. The agent-based simulation model presented in this paper deals with this trade off through the use of utility functions. The model simultaneously uses risk analysis and game analysis to address this strategic problem of applying short-term vs. long-term solutions. The model was tested on a model of Nalapaan village in the Philippines for the period between 2000-2003. The model equips community-level leaders (provincial governors) with a tool to understand the dynamics behind some of their intuitive observations. It provides the leaders with a tool to simulate and see the likely effects of changes in counterinsurgency policy. ${ }^{22}$

Schroden, Jonathan, Rebecca Thomasson, Randy Foster, et al. "A New Paradigm for Assessment in Counterinsurgency". Military Operations Research, vol. 18, no. 3, pp. 5-20 (2013).

The paper describes the authors' experience in designing and implementing a different assessment methodology on assessing counterinsurgency operations (irregular warfare) than the one that existed in the doctrine at the time for ongoing operations as part of the International Security and Assistance Force (ISAF) in 2011. This was a direct request by COM ISAF (dual hatted at the time as NATO and the US forces Commander) from the Afghan Assessment Group (AAG) in theater. Military assessment is a feedback mechanism for the commander on whether his plan works, and if not, makes recommendations for change. NATO doctrine on operations assessment is heavily rooted in the language and ideas of Effects-Based Approach to Operations (EBAO), debated and partially rejected for conventional operations by the US military. The authors deliberately decided not to use this methodology. The US and NATO methodology for campaign assessment included several campaign objectives and lines of operation (LOO) leading to them. On each LOO, lay several intermediate objectives (decisive conditions) as indicators of incremental progress towards the operational/campaign objectives. Each intermediate objective is assigned a set of mostly quantitative metrics to determine if the objective had been achieved or not and how close to achieving it. These metrics were displayed on a traffic-light like colour coding to show

\footnotetext{
${ }^{21}$ Shearer, Robert. “Operations Analysis in Iraq: Sifting Through the Fog of War”. Military Operations Research, Vol. 16, No. 2, pp. 63-71 (2011).

${ }^{22}$ Kucik, Paul and Elisabeth Paté-Cornell. "Counterinsurgency: A Utility-Based Analysis of Different Strategies". Military Operations Research, Vol. 17, No. 4, pp. 5-23 (2012).
} 
their achievement level, i.e., red being bad, green being good, and yellow/amber somewhere in the middle. This imprecise colour coding has been a point of discussion. The authors also found this methodology not holistic enough, saw a need for qualitative input including subordinate commanders' thoughts. They also LOOs were an artificial decoupling of the problem set being addressed. After going through all the relevant literature, talking to analysts, commanders in theatre, and looking at higher strategic guidance, they recommended to have two types of assessment, one on Strategic and the other on Campaign. They conducted both assessments along four system elements, namely Security, Governance, Socioeconomics, and Regional Relations. The last one was recommended by the authors. For strategic assessment, each of these four had sub-elements underneath. For campaign assessment, essential tasks to be achieved corresponding to those four areas were listed. They determined standards on which the accomplishment of essential tasks would be reported. These standards were levels 1 through 5, 1 being bad and 5 being good. Progress performance would be reported on what is called a radar chart for the campaign assessment and standard reporting templates were used for each essential task. Furthermore, each subordinate unit commander could see what the other had reported, thus allowing fruitful discussions. The reporting was a mix of qualitative and quantitative. One hour presentation was followed by a five-hour discussion by the Commanders. Outputs of the AAG were the Quarterly Strategic Assessment Report (QSAR), which would be sent to Joint Forces Command-Brunssum, and ISAF Commander's Assessment Conference. The new assessment methodology had several pros and cons as mentioned by the authors in the paper, yet it was used to assess progress in a counterinsurgency as part of ISAF operations. ${ }^{23}$

\section{CURRENT APPLICATIONS OF MILITARY OR}

Invasion of Georgia in 2008 and invasion and annexation of Crimea in 2014 were wake-up calls for a more assertive Russia with conventional forces. The changing political and military realities again dictated the need for a shift in analysis from counterinsurgency operations to analysis of large scale, force-on-force operations of conventional forces, reminiscent of Cold War times. Below, are some of such OR analysis examples to give the reader a flavour of how OR and its methods support decision making for such situations. There are also two technical analysis papers on fire support and anti-submarine operations, reminding those similar issues of WW2 with more advanced weapon systems.

Paciencia, Todd J, Daniel J. Richmond, John J. Schumacher, et al. "A Framework and System for Theatre Air Attrition Modelling". Military Operations Research, vol. 23, no. 2, pp. 41-60 (2018).

The authors present a framework, with a desired fidelity and a reasonable computation time, to calculate blue (friendly) air attrition and conduct force structure analysis by the Headquarters Air Force Studies, Analysis, and Assessments. The Theatre Attrition Modelling System (TAMS) uses the existing AFSIM (Analytic Framework for Simulation, Integration, and Modelling) to provide high-fidelity mission data, and uses the resulting attrition grid to simulate

\footnotetext{
${ }^{23}$ Schroden, Jonathan, Rebecca Thomasson, Randy Foster, et al. "A New Paradigm for Assessment in Counterinsurgency”. Military Operations Research, Vol. 18, No. 3, pp. 5-20 (2013).
} 
aircraft routing against enemy threats. Its higher fidelity compared to existing tools and significantly less computational burden allows a more rapid analysis capability for the US Air Force. ${ }^{24}$

Rogers, Matthew B, Brandon M. McConnell, Thom J. Hodgson, et al. "A Military Logistics Network Planning System" Military Operations Research, vol. 23, no. 4, pp. 5-24 (2018).

The US Military's supply network consists of 24 wholesale supply locations, around 33,000 retail supply locations in nearly 86 countries. It utilizes 10 different transportation modes, receives around 50,000 daily requisitions, and manages an inventory of 2.4 million lines which total close to $\$ 109$ billion in inventory. The US Army uses a database system composed of three different enterprise resource planning (ERP) tools and it is powered by the commercial off-the-shelf software system SAP. One of the three ERP systems is Global Combat Support System- Army (GCSS-Army, http://gcss.army.mil). The tool presented in this paper can be used with GCSS to create a planning tool to determine end-to-end logistical requirements for the US Army. The authors present and demonstrate the utility of a Military Logistics Network Planning System (MLNPS) that uses advanced analytics and mission-based forecasting in order to predict the demand for military repair parts, identify prospective choke points in an existing logistical network, and proposes alternatives to eliminate those choke points. The MLNPS can be run daily to ensure the US Army's logistics network operates in an efficient and cost-effective manner. It can also be run to determine the impact of potential disruptions such as enemy activity or austere weather conditions on the logistics network. It can be used during contingency planning and crisis action planning to determine logistical implications of the plan. The validation of the model involved using logistical data from the 2003 invasion of Iraq by applying the tool to Operation Iraqi Freedom (OIF) planning scenario to demonstrate the model's functionalities. The tool's capabilities to predict the location, timing, and magnitude of logistical backlogs (queueing) are demonstrated using data both from OIF and a notional operation scenario in Africa, southern Sudan, involving a notional task force consisting of a division-size unit deploying from continental United States (CONUS) to Africa and its logistical sustainment network. ${ }^{25}$

\section{David, Israel. "An Adaptive Mix Correction for Fire Support in Combat Operations". Military Operations Research, vol. 24, no. 4, pp. 23-36 (2019).}

When calculations are made to hit a target with an artillery gun, several factors such as range and location of the target (to calculate elevation and deflection of the gun), muzzle velocity (initial speed of the projectile), wind direction and speed are taken into account among other things. These calculations are never perfect and the first round on the target needs to be observed and adjusted by the forward observer in order to get sufficiently close to the target in subsequent firings, so that a fire-for-effect (all guns in a battery fire at the same target) command can be given. This fire adjustment is also called registration. The author argues that it is possible to use the information gathered while firing on this first target, to be able to shift fire on a different target, and fire for effect on the second target without having to adjust fire for a second time. The author presents a linear model and a constrained quadratic optimization problem for the proper mix of physical and

\footnotetext{
${ }^{24}$ Paciencia, Todd J, Daniel J. Richmond, John J. Schumacher, et al. "A Framework and System for Theater Air Attrition Modeling”. Military Operations Research, Vol. 23, No. 2, pp. $41-60$ (2018)

${ }^{25}$ Rogers, Matthew B, Brandon M. McConnell, Thom J. Hodgson, et al. "A Military Logistics Network Planning System” Military Operations Research, Vol. 23, No. 4, pp. 5-24 (2018)
} 
environmental factors, where the optimal mix depends on the given second target and thus is adaptive. The resulting shift accuracy is compared to that of an unadjusted fire and also to that of the currently used firing-shift algorithm. The author claims that this adaptive mix correction algorithm, still with room for improvement, could have a big impact on adjusting artillery fire. ${ }^{26}$

Where to Dip? Search Pattern for an Antisubmarine Helicopter Using a Dipping Sensor Author(s): Roey Ben Yoash, Michael P. Atkinson and Moshe Kress Source: Military Operations Research, vol. 23, no. 2 (2018), pp. 19-40.

Antisubmarine warfare was an important topic in WW2 as explained previously. It was also the fashion until the end of the Cold War. It has become a concern for the US in the wake of the situation in South China Sea and the re-emergence of an assertive Russia. The authors examine the effective usage of a helicopter equipped with a dipping sonar for antisubmarine warfare (ASW) missions to determine the dipping pattern and frequency. They consider the effects of helicopter speed and range, submarine speed, sensor detection radius, and travel time to the point of detection (via a surface ship with a sonar, anti-sub aircraft such as P-8, or a satellite), on the optimal dipping pattern. They determine that submarine velocity and submarine arrival time are the most critical. They recommend disjoint dips of the sonar unless the submarine velocity is known with a certain probability. $^{27}$

Klipstein, Michael and Kent D. Wall "A Picture Is Worth a 1,000 Words". Military Operations Research, vol. 25, no. 4, pp. 23-41 (2020).

The authors present a risk management decision aid for commanders in an offensive cyber operation setting. The four-question definition of risk applied to offensive cyber operations involve the following questions: What can go wrong? How likely is it to go wrong? If it goes wrong, what are the consequences? How do I feel about the consequences? Commander's objective hierarchy presented in the paper includes on top the objective to Maximize Effectiveness (of offensive Operations) It has the following sub objectives listed underneath: To Maximize Damage Inflicted, To Maximize Intel Obtained, To Minimize Detection, To Minimize Attribution if Detected, To Minimize Compromise if Detected. For each of these, the authors develop Commander's value functions. They use a multi-objective decision making methodology to capture commander's preferences. A bootstrap methodology is used to produce estimates of uncertainty in organizational subject matter experts (SMEs) estimates. This information is presented on a scatter plot diagrams (hence a picture is worth a thousand words!) for each risk management alternative. They demonstrate the implementation of their methodology with a risk management problem in offensive cyber warfare using real practitioners. 60 offensive cyber planners (31 military and 29 civilians) from six combatant commands of the US Department of Defence take place in the experiment. ${ }^{28}$

\footnotetext{
${ }^{26}$ David, Israel. “An Adaptive Mix Correction for Fire Support in Combat Operations".

Military Operations Research, Vol. 24, No. 4, pp. 23-36 (2019).

${ }^{27}$ Where to Dip? Search Pattern for an Antisubmarine Helicopter Using a Dipping Sensor Author(s): Roey Ben Yoash, Michael P. Atkinson and Moshe Kress Source: Military Operations Research, Vol. 23, No. 2 (2018), pp. 19 40.

${ }^{28}$ Klipstein, Michael and Kent D. Wall "A Picture Is Worth a 1,000 Words". Military Operations Research, vol. 25, no. 4, pp. 23-41 (2020).
} 


\section{CONCLUSIONS}

This paper provides a glimpse of Military OR's origins, recent past, and current application areas. This is by no means a fully comprehensive review of OR's origins, and current application areas. Yet, the author believes that there is enough flavour of the examples of initial applications of OR to ensure the understanding of how OR developed as an applied science in the years preceding and during WW2. In order to show the evolution of this applied discipline to its current state, recent and current examples are also provided. The author restricts, intentionally, the review to only the military applications of OR. The development of OR as a scientific disciple in the US, in other countries, and in NATO in the years after WW2 could be included in future studies of the subject. OR support during Korean, and Vietnam Wars could be explored in future studies as well, to provide a more detailed picture of the evolution of OR after WW2. The author believes that civilian applications of OR in the industry currently and also after WW2, development of its societies, and curricula in universities all over the world should be the subject of an entirely separate paper.

\section{BIBLIOGRAPHY}

Abdollahian, Mark, Brice L. Nicholson, Matthew Nickens, et al. "A Formal Model of Stabilization and Reconstruction Operations" Military Operations Research, vol. 14, no. 3, pp. 5-30 (2009).

David, Israel. “An Adaptive Mix Correction for Fire Support in Combat Operations”. Military Operations Research, vol. 24, no. 4, pp. 23-36 (2019).

Gaither, Norman. "Historical Development of Operations Research (1940-1960)". Academy of Management. Published Online: 13 Dec 2017 https://doi.org/10.5465/ambpp.1986.4976815

Klipstein, Michael and Kent D. Wall "A Picture Is Worth a 1,000 Words". Military Operations Research, vol. 25, no. 4, pp. 23-41 (2020).

Kucik, Paul and Elisabeth Paté-Cornell. "Counterinsurgency: A Utility-Based Analysis of Different Strategies”. Military Operations Research, vol. 17, no. 4, pp. 5-23 (2012).

Larnder, Harold. "OR Forum-The Origin of Operational Research." Operations Research, vol. 32, no. 2, pp. 465-476. (1984)

Lindsey, George. "Some Personal Recollections of Army Operations Research on Radar in World War II”. Canadian Military History. vol. 4: no. 2. (1995).

McCloskey, Joseph F. "OR Forum-British Operational Research in World War II." Operations Research, vol. 35, no. 3, pp. 453-470. (1987). https://doi.org/10:1287/opre.35.3.453

Paciencia, Todd J, Daniel J. Richmond, John J. Schumacher, et al. "A Framework and System for Theater Air Attrition Modeling”. Military Operations Research, vol. 23, no. 2, pp. 41-60 (2018). https://doi.org/10.1287/opre.32.2.465

Rogers, Matthew B, Brandon M. McConnell, Thom J. Hodgson, et al. "A Military Logistics Network Planning System” Military Operations Research, vol. 23, no. 4, pp. 5-24 (2018)

Shearer, Robert. "Operations Analysis in Iraq: Sifting Through the Fog of War". Military Operations Research, vol. 16, no. 2, pp. 63-71 (2011). 
Shearer, Robert and Brett Marvin. "Recognizing Patterns of Nation-State Instability that Lead to Conflict". Military Operations Research, vol. 15, no. 3, pp. 17-30 (2010).

Schroden, Jonathan, Rebecca Thomasson, Randy Foster, et al. "A New Paradigm for Assessment in Counterinsurgency”. Military Operations Research, vol. 18, no. 3, pp. 5-20 (2013).

Yoash, Roey Ben, Michael P. Atkinson and Moshe Kress "Where to Dip? Search Pattern for an Antisubmarine Helicopter Using a Dipping Sensor", Military Operations Research, vol. 23, no. 2 (2018), pp. 19-40 